\title{
Conflict of Resource Use Among Different Livelihood Group in Coastal Villages of South- Western Bengal Delta, Bangladesh
}

\author{
Sadhon Chandra Swarnokar, Md. Ashik-Ur-Rahman*, Sadia Islam Mou \\ Environmental Science Discipline, Khulna University, Khulna 9208, Bangladesh
}

Corresponding Author Email: ashik.ur.rahman@ku.ac.bd

https://doi.org/10.18280/ijsdp.150713

Received: 19 March 2020

Accepted: 15 September 2020

\section{Keywords:}

coastal livelihood, environmental degradation, common pool resources, resource conflicts, conflict management, Bengal delta

\begin{abstract}
People, ecosystems and resources are three crucial components for understanding resource use conflicts. This study examines resource use conflicts in two coastal villages of south-western Bangladesh, where access to resources are essential to rural livelihoods. Resource utilization conflicts can emerge when interests and needs of different users groups are incompatible or denied by each other. Considering these issues, this study has taken as an effort to explore the issues, reasons, stage, scale and impact of conflicts. Relevant data were collected through questionnaire survey, Focus Group Discussions (FGD) and Key Informant Interview (KII). The study found that rapid encroachment of crop land into shrimp farming, contrasting dynamic occupational practices, human made over use or overstrain of natural resources combined with environmental degradation and climate change, pose serious threat to human security. These rapid, and mostly unexpected changes provoke conflicts among the dominant resource user groups. Moreover, driver of conflicts and typological classification were addressed to make them comparable in the sense which one requires the most attention according to the predicted scale and urgency of impact. Conflict management strategies were discussed by four building blocks which might be a remarkable part of conflict prevention in the study area.
\end{abstract}

\section{INTRODUCTION}

Conflicts over resource use is a part of everyday life of the coastal people wherecompetition over natural resources, degradation of habitats and loss of Biodiversity affect human welfare [1-3]. Hellstrom [4] illustrated that competitions for finite natural resources, divergent attitudes, relationships and interactions among the stakeholders as well as institutional weakness underpin the rural livelihoods. This context is supported by several authors where competition over resources were highly focused for human made over extraction or overstrain of resources that may upsurge the risk of conflicts [1, 5-7].Generally, access to renewable natural resources become highly contested when parties disagree about the management, allocation, use or protection of natural resources $[1,3,6]$.

Coastal region is extraordinarily rich in terms of diversified ecosystem services and livelihood activities but conversely vulnerable due to its geographical shape and location $[8,9]$. The south-western coastal region of Bangladesh is a part of an active delta of lower Ganges-Brahmaputra-Meghna (GBM) drainage basin [10]. This is one of the most complex estuarine ecosystems of the world where the people govern their livelihood by diversified land use and occupational pattern [11]. This region is the home of millions of people but the coastline is mostly irregular and consist of a series of river and canal network which continuously changing their courses, flow velocity and natural land formation [12-14]. Conversely, this area is the hub of recurrent hydro-climatic disasters, erratic rainfall and temperature change, water logging, salinity intrusion, diverse land use changes $[15,16]$ and competitive resource consumption pattern [17-19].

Pattern of interactions among land, water and other natural resources refer to the bargaining processes among stakeholders in the pathway they extract resources, formulate new rules and demand action from other stakeholders [20-22]. Hence, the management of land, water, fisheries and forests resources are highly contrasting and challenging. This phenomenon is more prominent in coastal zone where access to and control over common-pool resources are essential to rural livelihoods [11, 18, 23, 24]. In addition, wide array of environmental stresses from inefficient natural drainage systems, waterlogged floodplains, salinity intrusion, large scale polderization (coastal enclosures) provoke violent conflict by increasing socio-economic vulnerability, reducing soil and water quality and thereby impact on agricultural diversity and productivity [10, 14, 25-27]. When ecosystem and resources are mostly challenged by weak institutions, fragile political systems and divisive societal complexities may fuel the spiral of violence or conflict. Therefore, this paper endeavors to assess the cases of disagreement and decipher the resource use conflicts among different livelihood group in coastal villages of south-western Bangladesh.

\section{MATERIALS AND METHODS}

\subsection{Study area}

The villages Bara Kupot and Henchi - preselected as they 
are peripheral to the coastline situated on the bank of Khalpetua river in Atulia Union of Shyamnagar, Satkhira in the southwestern coastal Bangladesh (Figure 1) around latitude $22^{\circ} 18^{\prime} \mathrm{N}$ to $22^{\circ} 22^{\prime} \mathrm{N}$ and longitude $89^{\circ} 08^{\prime} \mathrm{E}$ to $89^{\circ} 14^{\prime} \mathrm{E}$. The study area is included in Polder 15 . These villages were severely affected by cyclones Sidr during November 15, 2007 and Aila during May 25, 2009 in recent past. The Atulia union is on the periphery of the Sundarbans the largest single tract mangrove forest globally - being separated by the river Malancha and $30 \mathrm{~km}$ from the coast. Bara Kupot is closer to the Kholpetua and is separated from Henchiby a canal, locally called Arpangashia-Henchikhal, originated from the river Kholpetua [28]. These two coastal villages were selected as study area because natural disasters such as: cyclones, tidal surges, storms, saline water intrusion and water logging are prominent occurrences of this region [29]. In addition, land use and land-cover change is another major concern of their resource use pattern within the study area [30]. The livelihood and economy of Shyamnagar's inhabitants are based on shrimp culture, crop farming and the natural resources of Sundarban. Since the implementation of the polders, no large-scale government projects and management approaches have been implemented there apart from some roads constructed by the Local Government Engineering Department and minor support provided by the local NGO.

\subsection{Geological and hydro-geological setting}

Physiographically this area lies in the Ganges Tidal Floodplain as a broad bend of very low land - barely a meter above the sea level - and biophysically may be termed as immature delta [31]. Geochemically the soils are mostly noncalcareous grey floodplain and acid sulphate soils (saline) [32]. Lithologically, the area is composed of coarse to very fine sand, silt and silty clay up to a depth of $300 \mathrm{~m}$ with peaty soil and calcareous as well as non-calcareous soil at the top. The surface lithology of the area is of deltaic deposits which are composed of tidal deltaic deposits, deltaic silt deposits, and mangrove swamp deposits $[33,34]$.

The region experiences subtropical humid weather conditions and the maximum temperature reaches up to $35.5^{\circ} \mathrm{C}$ during summer and the minimum temperature is $12.5^{\circ} \mathrm{C}$ during winter [35]. The regional temperature shows a maximum decreasing trend of $3.1^{\circ} \mathrm{C}$ per hundred year whereas the minimum increasing trend is $1.9^{\circ} \mathrm{C}$ per hundred year for the period of 1960-2011. The average annual rainfall is around $1710 \mathrm{~mm}$ [36] and 78\% of the total rainfall is received between July to October - the monsoon season [37-39]. It is important to know geological and hydro-geological setting of a region because occupational and livelihood pattern in a coastal agrarian society primarily depends on geological location and climatic conditions of that region.

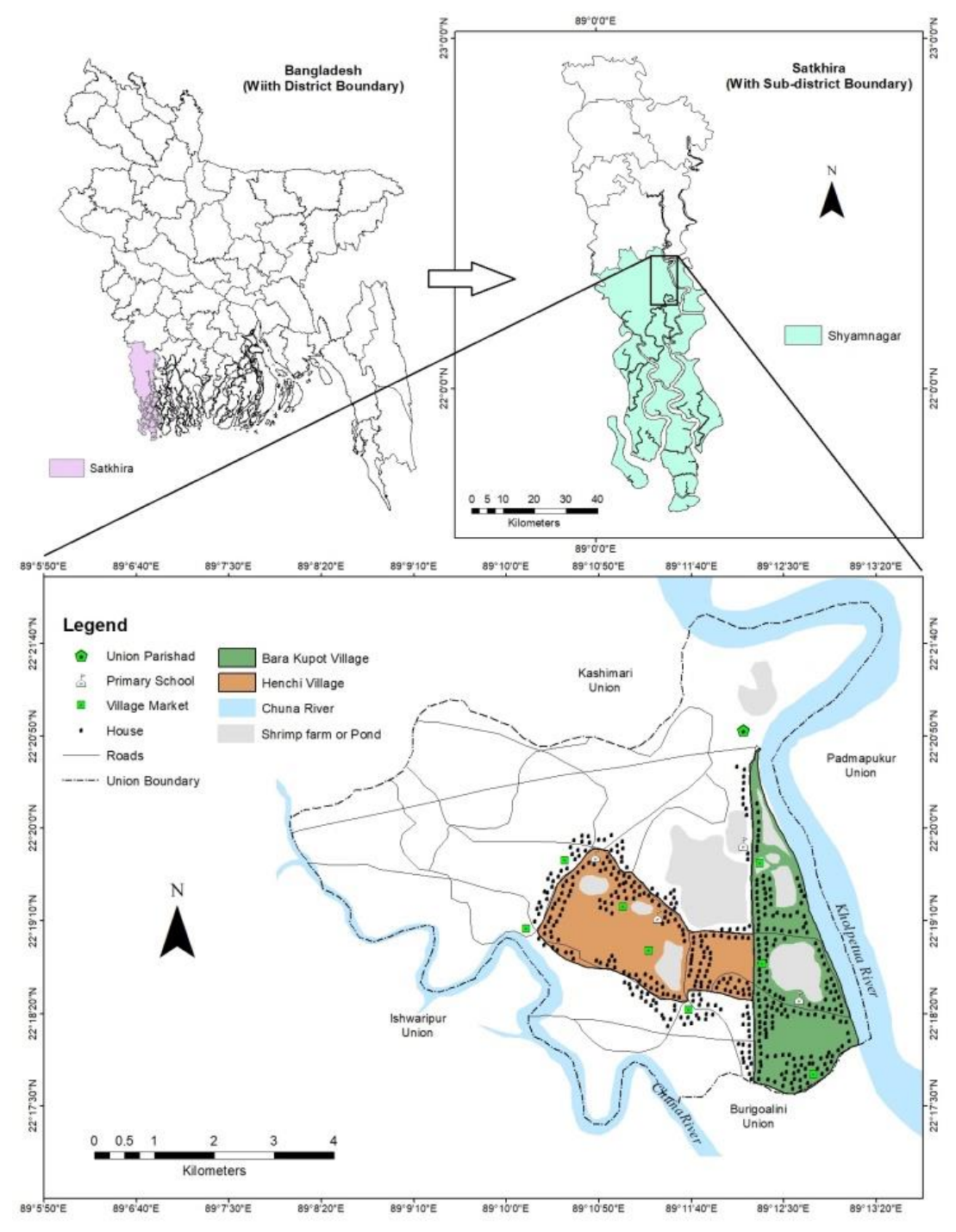

Figure 1. Location map of the study area 


\subsection{Sample size determination}

A total of 948 households $(\mathrm{HH})$ were recorded in Bara Kupot and 158 in Henchiwhere the people are involved in 29 different types of primary and secondary occupations. Correlation matrix of the primary socio-economic attributes of Bara Kupot and Henchiare performed and best relation were found between cultivable land area and total income of households. Since both these parameters are determinants of occupation the households were stratified accordingly where 12 households in Bara Kupot and 22 households in Henchi are lying outside the cluster and have not been considered here. The sample size $(n)$ for the rest of the households (936 for Bara Kupot and 136 for Henchi) was determined following Kothari [40] at $99 \%$ confidence level:

$$
n=\frac{z^{2} \cdot p \cdot q \cdot N}{e^{2}(N-1)+z^{2} \cdot p \cdot q}
$$

where, $N=$ population size $n=$ sample size $; p=$ sample proportion; $q=1-p ; z=$ standard variation at a given confidence level; and $e=$ acceptable error (the precision). At $99 \%$ confidence level, $z=2.5758 ; p=0.1 ; q=(1-0.1)=0.9 ; e$ $=0.05$.

Here, estimation shows that household sample size $(n)$ for Bara Kupot is 190 households and for Henchi it is 86 .

\subsection{Data collection}

The study investigated and analyzed socio-economic attributes and conflicting issues of the south-western coastal villages. Primary data were collected using a combination of semi-structured questionnaire, Focus Group Discussion (FGD), Key Informants Interview (KII) incorporated in Table 1. Other methods such as: transect walking, community visioning etc. were also conducted to explore local knowledge, livelihood activities and coping strategies of the villagers. The field visit was done purposively in two coastal villages under Shyamnagar Upazilla. Also, these villages are situated at the periphery to the Sundarbans. Along with agro and shrimp farming, a majority of the population of these villages sustains their livelihoods directly or indirectly on the Sundarbans.

Table 1. Methods and techniques used for data collection

\begin{tabular}{|c|c|c|}
\hline Methods & Purpose & Time \\
\hline $\begin{array}{l}\text { Questionnaire } \\
\text { survey }\end{array}$ & $\begin{array}{l}\text { To collect information on socio- } \\
\text { economic and livelihood attributes. }\end{array}$ & $\begin{array}{c}\text { January, } \\
2017\end{array}$ \\
\hline FGD & $\begin{array}{l}\text { To identify risk, livelihood, climate } \\
\text { change impacts, major disaster } \\
\text { impacts etc. } \\
\text { To explore the cases of disagreement } \\
\text { and resource use conflicts }\end{array}$ & $\begin{array}{l}\text { February, } \\
2017\end{array}$ \\
\hline KII & $\begin{array}{l}\text { To know about the biophysical- } \\
\text { livelihood strategies, respective } \\
\text { challenges, conflicting issues and } \\
\text { probable solutions. }\end{array}$ & $\begin{array}{l}\text { March, } \\
2017\end{array}$ \\
\hline
\end{tabular}

\subsubsection{Questionnaire survey}

A total number of 190 households for Bara Kupot and 86 households for Henchi were purposively selected for questionnaire survey from the baseline data. Questionnaire survey was performed to explore some general information (e.g. primary and secondary occupation, education, age etc.), observation of local environmental condition (e.g. changes of water and soil salinity, rainfall, temperature etc.), land type and land use changes (e.g. before and present situation and associated factors that govern their land use pattern). The questionnaire survey also focused on their farming pattern, natural phenomenon they observed for the last 10 years, health and sanitation etc.

\subsubsection{Focus group discussion (FGD)}

A focus group discussion was arranged with local inhabitants between age 25 years and 60 years with $35 \%$ female participants. There are ten FGD was conducted in the study villages ( 5 for Bara Kupot and 5 for Henchi). More than $50 \%$ participants are literate and belong to lower economic group. Majority of the participants are involved with shrimp farming, agriculture and manual labor. The female participants are mainly housewives but a good number of them also partially engaged with agriculture and homestead vegetation. Often forced displacement takes place when resource is scarce. At present, most of the participants do not own livestock because of the lack of grass lands. Potable water is scarce and they have to collect water either from Pond-Sand-Filter or from ponds travelling a long distance. A vast majority of the participants are eager to go for alternative occupation rather than depending on the natural resources. To derive important illustration and statement regarding conflict between user groups, topological classification of resource use conflicts and how the management approaches look like, focus group discussion method are used in the study.

\subsubsection{Key informant interview (KII)}

Key Informants Interview was performed on those who are knowledgeable, willingness to share information, communicative, impartial and have a role in the community or understanding of the phenomenon deeply. Thus, to know about background information, occupational disagreement and issues, management strategies, Resource use conflict: nature and causes, there are 10 number of KII were interviewed (Upazilla agriculture and fisheries officers (2); Teachers and researchers (2); NGO Executives and their representatives (2); Civil society and Media personnel (2) and 2 grass root people).

\section{RESULTS AND DISCUSSIONS}

\subsection{Socio-demographic profile}

The BBS (2011) recorded the population of Bara Kupot and Henchi together as 1698 where the total households residing in Bara Kupot is 269 with a population of around 1320 while in Henchi the total number of households is 93 with a population size of 378 .

However, our study differs from that of BBS [28] and the study record represent that total households living in Bara Kupot is 948 with the average household size is 4.9. The Henchi accommodates a total number of 158 households with the average household size is 4.1. The percentage of male and female ratio, different age group such as children and their school attending, representing age group, literacy rate and the demographic status of Bara Kupot and Henchi are mentioned in Table 2. 
Table 2. Socio-demographic profile of the study area

\begin{tabular}{|c|c|c|c|c|}
\hline \multicolumn{3}{|c|}{ Demographic parameters } & Bara Kupot & Henchi \\
\hline \multicolumn{3}{|c|}{ Total household } & 948 & 158 \\
\hline \multicolumn{3}{|c|}{ Household density } & 4.9 & 4.1 \\
\hline \multicolumn{3}{|c|}{ Total population } & 1320 & 378 \\
\hline \multirow{2}{*}{ Male- female percentage } & \multirow{2}{*}{\multicolumn{2}{|c|}{$\begin{array}{c}\text { Male } \\
\text { Female }\end{array}$}} & $46.89 \%$ & $47.08 \%$ \\
\hline & & & $53.10 \%$ & $52.91 \%$ \\
\hline \multicolumn{3}{|c|}{ Children (0-18) } & $33.70 \%$ & $36.60 \%$ \\
\hline \multicolumn{3}{|c|}{ Working force (15-64 years age) } & $66.20 \%$ & $61.10 \%$ \\
\hline \multirow{2}{*}{ Education } & \multicolumn{2}{|c|}{ Formal } & $75 \%$ & $80 \%$ \\
\hline & Non- & & $25 \%$ & $20 \%$ \\
\hline \multicolumn{3}{|c|}{ Major representing age group } & $27-35$ years $(37 \%)$ & $22-33$ years $(40.1 \%)$ \\
\hline \multicolumn{3}{|c|}{ Literacy rate } & $54.80 \%$ & $65.80 \%$ \\
\hline \multirow{4}{*}{$\begin{array}{l}\text { HH members in occupational } \\
\text { group }\end{array}$} & \multirow{2}{*}{ Agro- based } & Max & 8 & 5 \\
\hline & & Min & 3 & 3 \\
\hline & Non-agro & Max & 10 & 8 \\
\hline & Based & Min & 3 & 3 \\
\hline \multirow{2}{*}{ Farmers } & \multirow{2}{*}{\multicolumn{2}{|c|}{$\begin{array}{c}\text { Male } \\
\text { Female }\end{array}$}} & $25.20 \%$ & $31.10 \%$ \\
\hline & & & $28.30 \%$ & $36.10 \%$ \\
\hline
\end{tabular}

(Source: Household survey, 2017)

\subsection{Existing resources}

Livelihoods in the coastal zone are varied, often influenced by different resource use pattern. Almost $80 \%$ of coastal villagers depend on agro and aquaculture based activities to govern their livelihood. As consumption increases, the villagers face growing shortages of vital natural resources such as freshwater, cropland, forests, fisheries and other wildlife. Thus, a significant number of people are directly or indirectly or indirectly dependent on the resources of the Sundarbans for their livelihood support. Fishing and crab collection from the small creeks in the Sundarbans are the primary occupation for those depended totally on the Sundarbans. The local people also collect timber, fuel wood, honey, goran and golpata from the Sundarbans when opportunity arrives. Table 3 provides an outline about the key resources that play a major role in the livelihood of the coastal villagers.

Table 3. Natural resources in the study villages

\begin{tabular}{ccc}
\hline Resource & Features & Utilization Pattern \\
\hline Land Resource & Landforms formed from the huge amount of alluvial sediments & $\begin{array}{c}\text { Household construction, Fish culture, Crop } \\
\text { production }\end{array}$ \\
Water Resource & $\begin{array}{c}\text { Aquaculture based saline water for shrimp farming, Pond and river } \\
\text { water used for agriculture, Drinking water- pond, tubewells and PSF } \\
\text { Cow, Goat, Crab, Shrimp, Fruits, Rice, Vegetables }\end{array}$ & $\begin{array}{c}\text { Aqua culture, Agriculture, House construction, } \\
\text { Brick production, Roads and communication } \\
\text { Provide food, Meet nutrition, deficiency }\end{array}$ \\
Forest Resource & $\begin{array}{r}\text { Mainly social forest, Heterogeneous mixture of plants is observed, } \\
\text { Small timber for building huts and houses and grass for grazing and } \\
\text { small feeding livestock. }\end{array}$ & $\begin{array}{c}\text { Provide oxygen, Used as fuel wood, Medicinal } \\
\text { plants, Provide fruits to people }\end{array}$ \\
Energy Resource & Fuel wood, bushy plants and solar energy. & $\begin{array}{c}\text { Collection of fuel wood, Utilization of solar } \\
\text { energy but not significant. }\end{array}$ \\
\hline Source:
\end{tabular}

(Source: Household survey, FGD and KII, 2017)

\subsection{Preface to occupational and land use shift: resource use conflicts}

After the construction of coastal embankments in 1960, the people were heavily engaged with the agriculture activities. Though they have got only one season crop but that agro based activities were more environment friendly (95\% people's perception). In addition, it supported their housing materials as well as daily fuel and livestock rearing ( $88 \%$ people's perception). This agricultural practice was highly profitable for 10 or 15 years but after a particular time period, severe water logging due to higher siltation on river bed and sudden flooding in the rainy season posed a great threat to the agro production.

In the meantime, some elite people started shrimp farming outside the embankment along both side of river and canal through grabbing khash land in 1980. At that time, it was completely natural based farming and there was no need shrimp fry, fertilizer and other water treatment chemicals. As it was highly profitable than agro farming, significant number of people engaged with shrimp farming inside the coastal enclosure (embankment) intentionally to gain benefit (35\% people's perception) whereas other people involved without getting any alternative sustainable land use practices $(65 \%$ people's perception).

After 1990, the people were heavily engaged with extensive shrimp farming which has become a major export industry in this coastal zone. A large number of agro fields were converted into aquaculture chiefly shrimp farming. Thereafter, big gher were converted to small gher area through the involvement of small agro farmer in the shrimp farming (95\% people's perception). Although shrimp farming was highly profitable for 10 or 15 years but at present it already appeared as vulnerable occupational practices. Table 4 insights the vulnerability and problems of three resource dependent livelihood group. 
Table 4. Current problematic issues are faced by dominant resource dependent stakeholders

\begin{tabular}{c|c|c}
\hline Agro cultivators & Shrimp cultivators & Mix cultivators \\
\hline $\begin{array}{c}\text { 1. The support system is not favorable for } \\
\text { crop production. }\end{array}$ & $\begin{array}{c}\text { 1. Limited water exchange facilities due to netting, } \\
\text { illegal grabbing- sluice gate, canal, river. } \\
\text { 2. Lack of natural shrimp fry and sudden death of } \\
\text { shrimp }\end{array}$ & $\begin{array}{c}\text { 1. The support system is not } \\
\text { favorable except few areas. } \\
\text { 2. Salinization of soil and water is a } \\
\text { major concern. } \\
\text { the surrounding shrimp farm land. }\end{array}$ \\
$\begin{array}{c}\text { 3. High investment cost for seed, chemical, } \\
\text { fertilizer and low market price. }\end{array}$ & $\begin{array}{c}\text { 3. High investment for land leasing, food, chemical. } \\
\text { 4. High investment cost for land. } \\
\text { preparation, food, chemical. }\end{array}$ \\
$\begin{array}{c}\text { 4. Water logging, sudden flooding, tropical and soil salinity } \\
\text { cyclones. }\end{array}$ & 5.Uncertain production & $\begin{array}{c}\text { 4. Water logging and flooding. } \\
\text { 5. Production vulnerability. }\end{array}$ \\
\hline 5. Low production & &
\end{tabular}

(Source: Household survey, FGD and KII, 2017)

\subsection{Stakeholders involved in conflicts}

Although the people are involved more or less 15 kinds of occupational activities but $90 \%$ stakeholders and community people conflict with each other under three major livelihood groups to support their livelihood processes. Among diversified occupational livelihood processes agriculture, shrimp farming and mix cultivation are three major dominant livelihood practices that govern the livelihood of $80 \%$ coastal people. In both villages conflicts are caused by disputes among the group of stakeholders involving one or more of the following root causes corresponding their interests, goals, relationships, positions and capacities in decision making process (Table 5).

Table 5. Description of stakeholders involved in the conflict

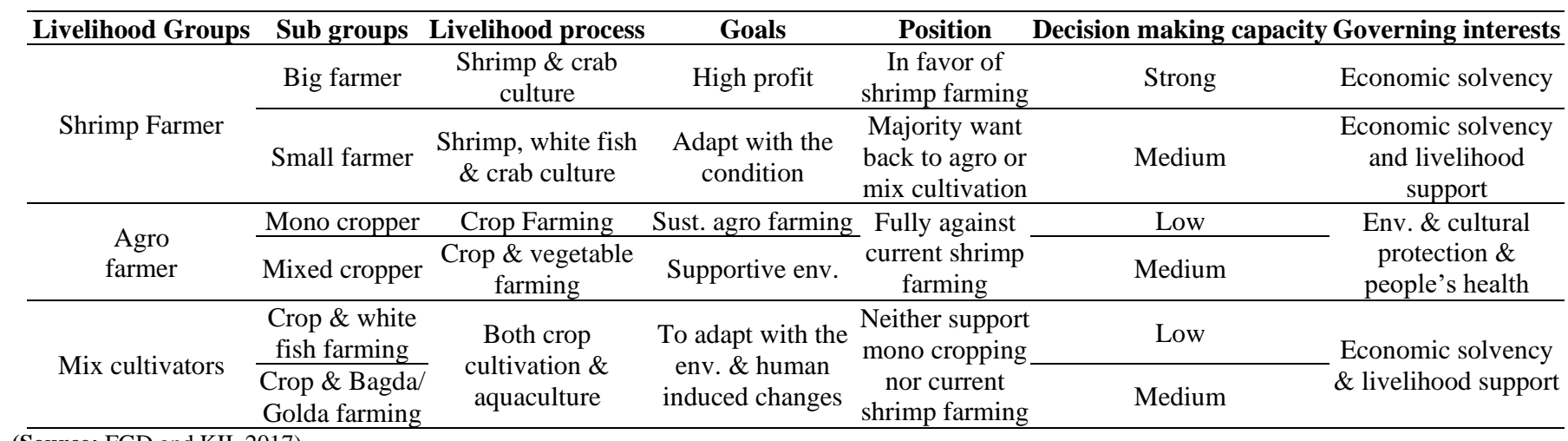

(Source: FGD and KII, 2017)

\subsection{Fundamental drivers of conflict over resource use}

Conflicts related to resources and its management is now more troublesome than ever earlier due to stressed environmental condition [41]. Growing shortages of vital renewable resources, combined with environmental degradation and climate change pose fundamental threats to livelihood security. Separately or in combination with other factors it causes competition over scarcity of natural resources termed as Driver-1. Conflict itself is not a negative phenomenon until it remains under proper management around their ownership, allocation and control. However, under socio-economic and environmental fragile state, poor governance (Driver-2) over environmental and resources management lack the dimensions to resolve disputes or depletion of natural resources, can lead to violent conflict. Under Driver-3, conflict becomes challenging depending upon rate of use, who should have access to and control over resources, and who can influence decisions regarding their allocation and sharing of benefits. Although, there are some other sub drivers may influence resource use conflict but conflict prevention strategies must often take into these three major driver as these three drivers can interact with and reinforce each other

Driver-1 refers to competition over scarcity of natural resources. Nearly three quarter of the participants think that when the supply of renewable resources such as land, water, croplands and forests are not adequate to meet the local demand then it creates a situation which forces the inhabitants to compete over resources. Both two coastal villages are very close to periphery of Sundarbans and open to the Bay of Bengal. The study suggest that the Bara Kupot villagers are more competing than that of Henchi due extensive shrimp farming and high level of water and soil salinity in the cultivable land. Competition starts when different groups in a society face unequal resource access (structural scarcity) and therefore causes imbalance between supply and demand when the scarcity arise for a specific renewable resource (demand induced scarcity) as the demand cannot be met by the existing supply (supply induced Scarcity).

Driver-2 indiates poor governance over environmental and resources management. In the study villages there is no proper planning and implementation strategies that keep pace between their socio-economic processes and ecological processes. The study suggests that conflict over resource use caused not only increasing scarcity and competition between groups but also be the sense of injustice, inequity and marginalization. The land and water use is mainly controlled by the big shrimp farmers, elite and powerful political groups in absence of good governance and effective land use zoning.

Driver-3 denotes trans-boundary natural resource dynamics and pressures. Trans-boundary natural resource dynamics and pressures are mainly caused by four types of trans-boundary dynamics and pressures that emerge conflicts among paddy, 
shrimp and mix cultivators- 1) unequal or inflexible use (13\% people's opinion); 2) environmental degradation (27\% people's opinion); 3 ) land use changes (50\% people's opinion) and 4) illegal exploitation of resources (10\% people's opinion). This is generally caused by unclear boundary disputes and growing demand for resources. Finally, river and canals of the study villages are grabbed by different beneficiary and powerful group that may act as the stimuli of resource use conflict.

Table 6. Resource use remarks and conflicts over different user groups

\begin{tabular}{|c|c|c|c|}
\hline Governing livelihood & User group & Problematic remarks & Livelihood threat \\
\hline \multirow[t]{2}{*}{ Shrimp farming } & Big farmer & $\begin{array}{l}\text { Get enough river water and suitable for shrimp culture but sometimes } \\
\text { conflict with the sluice gate operator, LG and illegal occupier of } \\
\text { common pools of resources }\end{array}$ & Uncertain production \\
\hline & Small farmer & Get less water. Conflict with sluice gate operator, LG and big famer & $\begin{array}{l}\text { Production and income } \\
\text { vulnerability }\end{array}$ \\
\hline \multirow{2}{*}{ Agro farming } & Mono farmer & $\begin{array}{l}\text { Get less water and faces salinity intrusion, water logging. Conflicts } \\
\text { with shrimp farmer and LG }\end{array}$ & $\begin{array}{l}\text { Yield reduction, } \\
\text { vulnerable livelihoods }\end{array}$ \\
\hline & Mixed farmer & $\begin{array}{l}\text { Get less water and faces salinity intrusion. Conflicts with shrimp farmer } \\
\text { and LG }\end{array}$ & vulnerable livelihoods \\
\hline \multirow[b]{2}{*}{ Mix cultivating } & $\begin{array}{l}\text { Crop and white fish } \\
\text { farming }\end{array}$ & \multirow{2}{*}{$\begin{array}{l}\text { Face difficulties in land and water management. } \\
\text { Conflicts with both agro and fisheries communities }\end{array}$} & $\begin{array}{c}\text { Short term } \\
\text { sustainability }\end{array}$ \\
\hline & $\begin{array}{c}\text { Crop and } \\
\text { Bagda/Golda farming }\end{array}$ & & $\begin{array}{l}\text { Short term } \\
\text { sustainability and } \\
\text { production }\end{array}$ \\
\hline \multirow[t]{2}{*}{ Households } & Poor & $\begin{array}{l}\text { Scarcity of food, fresh water, cultivable land etc. Collect resources } \\
\text { from common pools and forest. } \\
\text { Conflict with lease holders }\end{array}$ & $\begin{array}{l}\text { Resource scarcity and } \\
\text { livelihood vulnerability }\end{array}$ \\
\hline & Rich & Purchase most of their food items from market & $\begin{array}{l}\text { High price rate and } \\
\text { resources scarcity }\end{array}$ \\
\hline
\end{tabular}

(Source: Household survey, FGD and KII, 2017)

\subsection{Different resource use groups in the study villages}

In the study villages, socio-economic condition of the coastal community is mostly depending on paddy, shrimp and mix cultivation practices. The study has found four major resource user groups who are predominantly conflict upon each other due to dissimilar demand, varied perception, occupational and livelihood threats. Each user group predominantly seeks their personal gain and tries to dominate other user group based on their capacity and capability to control over the resources. Competing interests over natural resources can be a source of conflict and transform both inter and intra user depending on livelihood responses, the mix of drivers, existing governance assemblies and the level of conflict intensity incorporated in Table 6.

\subsubsection{Shrimp farming group}

Shrimp farmers are divided into two groups: big farmer (Big gher owner: culvate more than 10 acre land) small farmer (small gher owner: cultivate less than 10 acre land). The number of big gher owner is comparatively higher in Bara Kupotthan that of Henchi. They are the leading group and control almost whole water and land resources expressly in Bara Kupotvillage. They are the occupier of major cultivable land and use direct saline water for shrimp farming. They involve both illegal and legal fishing and always compete with small shrimp and agro farmers. Both big and small farmers are responsible for gradual increase in soil and water salinity which negatively impact on crop production, home stead vegetation and even the whole biodiversity over the regions. Most of the big shrimp farmer think that no other farming could be successful except shrimp while the small farmer is divided in their opinion because they don't know which farming practices should be adapted for long term sustainability.

\subsubsection{Agro farming group}

They are two types of agro farming group found in study villages. The mono croppers are mainly depending on paddy cultivation but they prefer at least two times crop production over the year round. They are victimized by the shrimp farmers, sluice gate operators and so called legal occupier of common pools resources. In fact, they are facing the harsh reality biophysical and environmental changes (e.g. increasing water and soil salinity). Most of the agro farmers think that sustainable agricultural practices are badly needed to protect the environment and uphold ecosystem services. Although it is less profitable but it can support other livelihood facilities such as fuel, food, livestock, more employment opportunities and also favorable support system for home stead vegetation, floral and faunal enrichment.

\subsubsection{Mix cultivator group}

The mix cultivators are principally divided in two part-one who seek to cultivate both paddy and white fish and another who seek to both cropping and bagda or golda culture according to seasonal variation all the year round. Both group of people prefer environmental protection along with economic solvency to support their present and future livelihood. Except few cases their land and water management are not in favor for such combine culture. Most of them believed that sustainable mix cultivation practices can open a new pathway of coastal people.

\subsubsection{Household group}

The communities who are rich are largely service holder or businessman. They lead their life depending on the purchasing capacity which is chiefly income based. The poor households 
are the principal resource collector from common pools and forest resources. Competition among different livelihood groups (e.g. farming, livestock, fishing etc.), variation in resources availability and sudden contraction of natural resource supply may impact on household group whereas commercialization of common pools resource may escalate the violence of disputes.

\subsection{Social coalition formation over resource uses}

At present, good numbers of people want back to traditional ago-based farming or environment suitable mix cultivation practices. But most of the resources are under so called legal occupies and elite or powerful group of the society still now. The existing socio-economic vulnerability contributes to occupational instability when they overlap with other interactive factors such as vulnerable livelihood, demographic pressures, natural calamities, socio-ecological changes and climate change threats. Figure 2 depicted how natural resources play a central role in coastal livelihood and have a critical role in legitimizing and shaping of the resource conflict. In coastal social setup, the relationship between the supply of resources and the number of resource users, which even in normal conditions is problematic concerning who should have access to and control over resources.

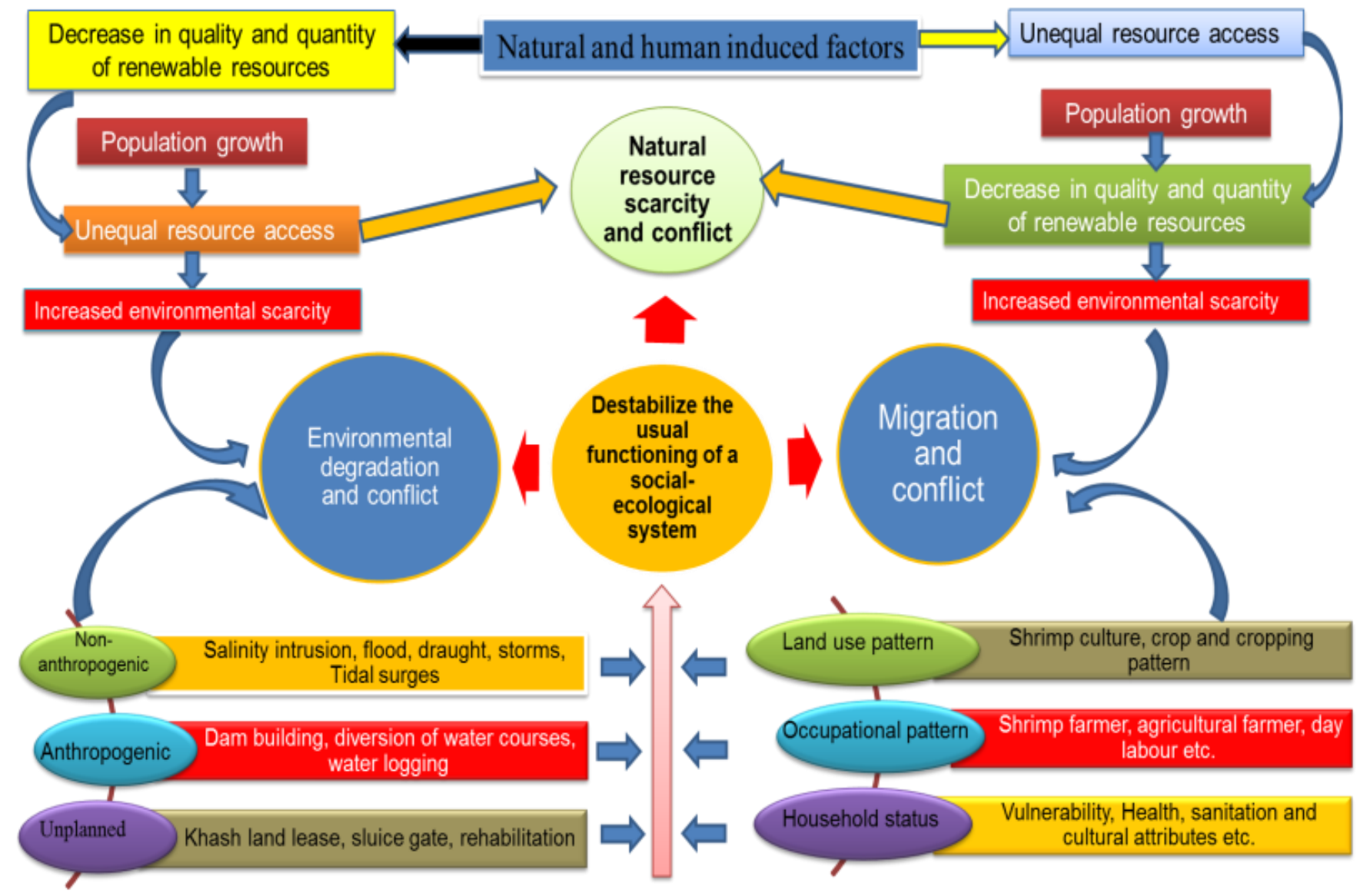

Figure 2. Social networks in coalition formation over resource use cases in coastal livelihood

Climatic variability (e.g. salinity intrusion, flood, cyclones etc.); human made interventions (e.g. dam building, embankments etc.) and larger struggle over political, economic, cultural, ownership etc. issues destabilize the usual function of social ecological system. In this context, scarcity of livelihood essentials, growing demand, unequal resource access and decrease in quality and quantity of resources are alleged the ways of conflict formation among the resource user. An intuitive interactive pictorial view can be found from the following figure where people, environment and natural resources interact in combine that have provoked wide-spread concerns over environmental resource scarcity and social impacts.

\subsection{Typological classification of resource conflicts}

Typological classification is a systematic differentiation of conflicts which is very significant for comparative analysis and assessment of environmental conflicts [42, 43]. It is mainly used for labeling the resources use conflicts. Although their characterization involves several factors, actors and dimensions but possible future evolutions can be obtained from classification, comparisons and generalizations of the conflict on the basis of objective of analysis and characteristics. Based on the abovementioned, a combination of Cadoret [44], Skutsch [45], Rupesinghe [46] and Warner [47] classification were used for typological classification of resource use conflicts.

\subsubsection{Classification by dynamics/manifestation over time}

This category of typological classification is based on [44], who labeled the conflict's manifestation over time as chronic, anticipation, hushed or deferred and hybrid. Form the conflict classification it is found that both villages are under chronic and anticipation conflict. Chronic in the sense because it is spread over a relatively long period of time $(+10 \mathrm{y})$ and which 
is characterized by several crises. It is anticipation conflicts because majority of the people express a form of fear about their future how their future look like! They also anticipate the consequences of change, without having a clear vision of infrastructural development continuing the change in practice, in landscape or in the function of ecosystem [44], The classification only varies in case of forest resources where it is only under anticipation types (as shown in Table 7).

\subsubsection{Classification by underlying cause/substance}

This typological classification is based on Skutsch [45], which provides an idea of what the underlying cause is: conflicts over access; conflicts due to change in resource quality and availability; conflicts regarding authority over resource; conflicts that are value based; conflicts associated with information processing and availability; and conflicts occurring for legal/policy reasons. This classification is very complex because each resources conflict is related to a different cause/reasons from which a certain type act upon principal under-lying cause. The following table (Table 8) provides an overview about the underlying causes of different resource conflicts.

\subsubsection{Classification by scale}

Warner's [47] classification used to typify the different resource conflict at conventional scale and the respective inter / infra and trans-variations in natural resource conflicts. He proposes a typology that is more relevant for environmental and natural resource conflicts and distinguishes them.
Conflicts over land and water resources scaled under infra micro-micro conflicts (boundary disputes, elite capture of benefits, community differences) and micro-macro conflicts which is related to environmental problems and contradictory resource needs. Typological classification for food and energy resources are also under micro-macro conflicts scale whereas forest resources conflicts scaled under inter micro-micro categories. The above table (see Table 9) gives an overview of the typological classification of resources conflicts in the study villages.

\subsubsection{Classification by stage}

Typological classification of environmental conflicts by stage allows discerning the evolution of the conflict and its present situation according to Rupesinghe [46], who distinguishes the five different 'stages' of conflict, or 'cycle of conflict'. An evolving conflict can be subject to a new negotiation process that provide an insight on how far the conflict is evolved and shows how it can be resolved.

Table 10 gives an overview of the resource use conflict cases by stages which reveals that in case of water and land resources conflicts over resources use are in transformation stage which urgently need new environment friendly management and institutional development. In case of food resource conflicts, it is under endurance stage and to minimize this conflict community empowerment and/or mediation processes already have taken. Conflict over forest resources is under formation stage and properly addressing at this stage conflict may not escalate and manifest itself.

Table 7. Typological classification of resource conflict cases by dynamics/manifestation

\begin{tabular}{|c|c|c|c|c|c|c|c|c|}
\hline \multirow{2}{*}{$\begin{array}{l}\text { Types } \\
\text { Cases }\end{array}$} & \multicolumn{2}{|c|}{ Chronic } & \multicolumn{2}{|c|}{ Anticipation } & \multicolumn{2}{|c|}{ Flushed or deferred } & \multicolumn{2}{|c|}{ Hybrid } \\
\hline & Bara Kupot & Henchi & Bara Kupot & Henchi & Bara Kupot & Henchi & Bara Kupot & Henchi \\
\hline Water resources & 1 & 1 & 1 & 1 & & & & \\
\hline Land resources & 1 & 1 & 1 & 1 & & & & \\
\hline Food resources & 1 & 1 & 1 & 1 & & & & \\
\hline Forest resources & & & 1 & 1 & & & & \\
\hline Energy resources & 1 & 1 & 1 & 1 & & & & \\
\hline
\end{tabular}

Table 8. Typological classification of environmental conflict cases by underlying cause

\begin{tabular}{|c|c|c|c|c|c|c|c|c|c|}
\hline \multirow{2}{*}{$\underbrace{\text { Types }}_{\text {Cases }}$} & \multicolumn{2}{|c|}{$\begin{array}{c}\text { Change in res. quality } \\
\text { \& availability }\end{array}$} & \multirow{2}{*}{$\begin{array}{c}\text { Infringements } \\
\text { over access } \\
\text { Bara Kupot Henchi }\end{array}$} & \multicolumn{2}{|c|}{$\begin{array}{l}\text { Conflicts that are } \\
\text { value based }\end{array}$} & \multicolumn{2}{|c|}{$\begin{array}{l}\text { Authority over } \\
\text { resource }\end{array}$} & \multicolumn{2}{|c|}{$\begin{array}{c}\text { Availability of legal / } \\
\text { policy reasons }\end{array}$} \\
\hline & Bara Kupot & Henchi & & Bara Kupot & Henchi & Bara Kupot & Henchi & Bara Kupot & Henchi \\
\hline Water resources & 1 & 1 & 1 & & & 1 & & & \\
\hline Land resources & 1 & 1 & 1 & & & 1 & & & \\
\hline Food resources & 1 & 1 & & 1 & 1 & & & & \\
\hline Forest resources & & & 1 & & & & & 1 & 1 \\
\hline Energy resources & 1 & 1 & & 1 & 1 & & & & \\
\hline
\end{tabular}

Table 9. Typological classification of environmental conflict cases by scale

\begin{tabular}{|c|c|c|c|c|c|c|c|}
\hline \multirow{2}{*}{$\underbrace{\text { Types }}_{\text {Cases }}$} & \multicolumn{2}{|c|}{$\begin{array}{l}\text { Infra micro-micro } \\
\text { conflicts }\end{array}$} & \multicolumn{2}{|c|}{ Inter micro-micro conflicts } & \multicolumn{2}{|c|}{ Micro-macro conflicts } & $\begin{array}{l}\text { Conventional scaling: local, } \\
\text { regional, national etc. }\end{array}$ \\
\hline & Bara Kupot & Henchi & Bara Kupot & Henchi & Bara Kupot & Henchi & Bara Kupot Henchi \\
\hline Water resources & 1 & 1 & & & 1 & 1 & Local vs. national \\
\hline Land resources & 1 & 1 & & & 1 & 1 & Local \\
\hline Food resources & & & & & 1 & 1 & Local vs. regional \\
\hline Forest resources & & & 1 & 1 & & & Regional vs. national \\
\hline Energy resources & & & & & 1 & 1 & Local \\
\hline
\end{tabular}


Table 10. Typological classification of resource conflict cases by stage

\begin{tabular}{|c|c|c|c|c|c|c|c|c|c|c|}
\hline \multirow{2}{*}{ Types } & \multicolumn{2}{|c|}{ Conflict formation } & \multicolumn{2}{|c|}{ Conflict manifestation } & \multicolumn{2}{|c|}{ Conflict endurance } & \multicolumn{2}{|c|}{ Conflict management } & \multicolumn{2}{|c|}{$\begin{array}{c}\text { Conflict } \\
\text { transformation. }\end{array}$} \\
\hline & Bara Kupot & Henchi & Bara Kupot & Henchi & Bara Kupot & Henchi & Bara Kupot & Henchi & Bara Kupot & Henchi \\
\hline Water resources & & & & & & & & & 1 & 1 \\
\hline Land resources & & & & & & & & & 1 & 1 \\
\hline Food resources & & & & & 1 & 1 & & & & \\
\hline Forest resources & 1 & 1 & & & & & & & & \\
\hline Energy resources & & N.B.: & $\begin{array}{c}1 \\
\text { represent the }\end{array}$ & $\begin{array}{c}1 \\
\text { ge of }\end{array}$ & ources co & cts in & tudy villa & & & \\
\hline
\end{tabular}

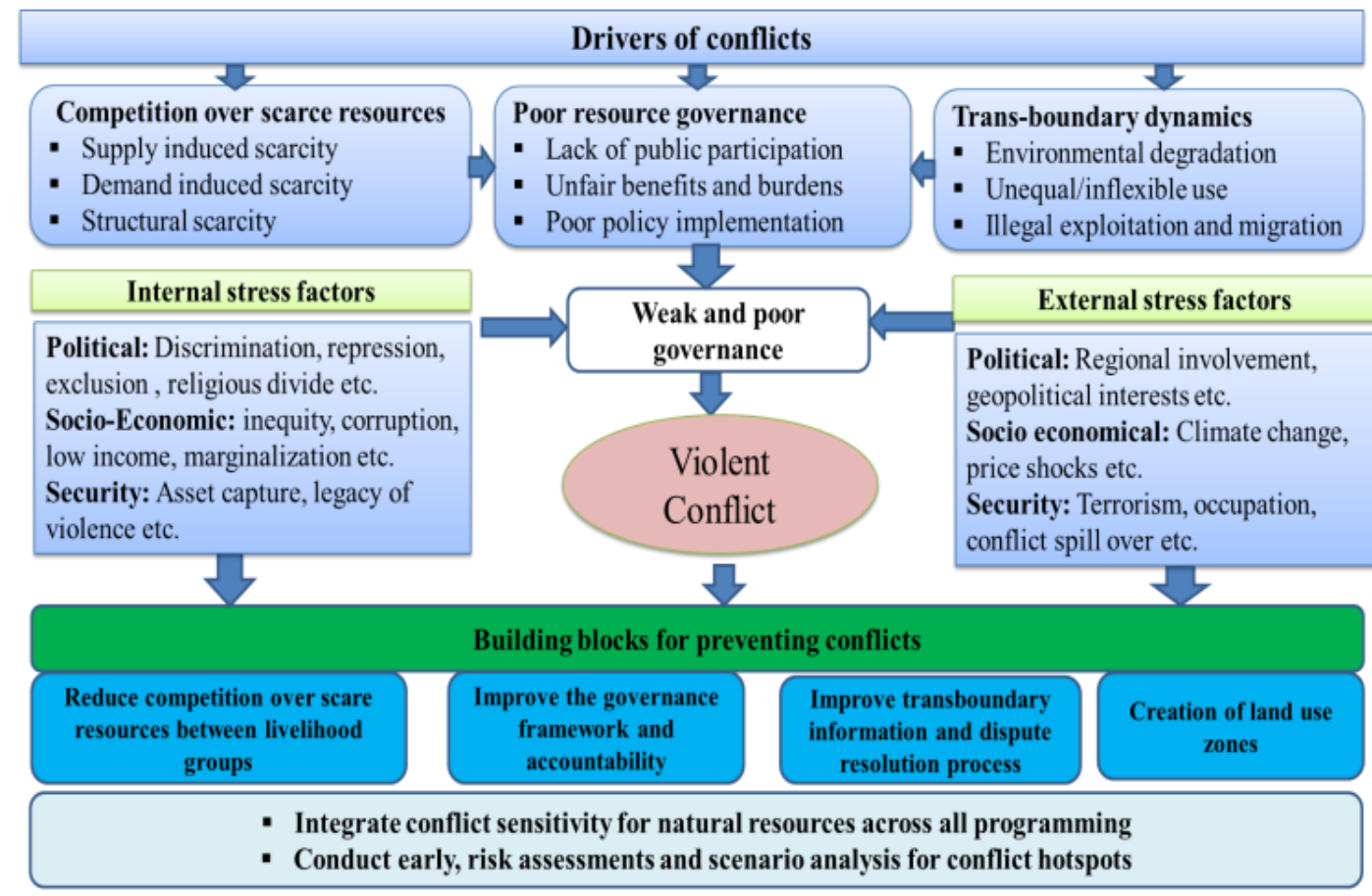

Figure 3. Drivers and stress factors of environmental strategies for preventing conflicts over natural resources (Adopted from UNDPA [48] and UNICEF [49])

\subsection{Conflict prevention strategies}

In most cases, conflicts over renewable resources interact with existing political, socio-economic and stress factors, requiring a response on multiple levels derived from bottomup, cross-sectorial participation and collective action at micro to macro levels [48]. Disputes and grumbles over natural resources act as the sole cause of conflict when they overlap with other factors. To abate these types of conflicts, most respondents put emphasis on effective inlet and outlet water exchange along with homestead buffer zoning to save the home gardening from salt intrusion. In addition, to recover occupied water channels from illegal or so-called legal occupiers need good governance. Competition over scarce resources between livelihood groups, poor resource governance and trans-boundary resource use scheme are the fundamental drivers of conflicts. When internal stress factors (e.g. political: discrimination, exclusion, religious divide etc.; socio-economic: inequality, corruption etc. and social security: asset capture, legacy of violence etc.) overlap with external stress factors such as political (e.g. geopolitical interest, regional involvement etc.), socio-economical (e.g. climate change) and occupational security, determine whether the conflict becomes violent or not.

The conflict prevention program must consider four main building blocks and supporting interventions (see Figure 3 ).
The first one is reduced competition between livelihood groups over scare resources by supporting the coastal livelihood through management of biophysical attributes and by increasing the resource availability through preventing environmental degradation. Secondly, establishing adaptation framework, strengthening capacity of civil society and engaging them in the decision making processes can secure the livelihoods by ensuring good governance, accountability and dispute resolution.

Although the third one is very complex but resource-sharing agreements and joint institutions can contribute to minimize conflict over trans-boundary management and cooperation. The last one is proper land use zoning over risk assessments and scenario analysis would be a significant part of conflict prevention strategies.

\section{CONCLUSION}

Natural resources critically govern the livelihood of two coastal villages, namely Bara Kupot and Henchi. Diversified interests, goals, position and relationships of different resource user group contribute to instability and conflict when they disagree about the management, ownership, distribution, use and safeguard of natural resources. Competition over scarcity, poor governances and trans-boundary resource dynamics 
under increasing pressures act as the sole cause of conflict. This is exemplified by the large scale occupational shifting, abrupt land use changes and illegal resources capturing, which in turn challenge the livelihood dependencies and minimum access to basic right to those resources. The main focus in this study was to find out the combine ranking which express the overall assessment of conflicts and make a comparable sense about "which conflict requires the most attention". With such constraints and complexities it is very difficult to ensure resources availability and minimizing the risk of conflicts. For these reasons, minimizing conflicts over resources require a set of approaches which include improved resource governance and sustainability, better responsibility, more community participation, stronger mechanisms for dispute resolution, improved trans-boundary resource management and so on. Further study is needed for taking strategic action and it's implementation in preventing resource use conflicts.

\section{ACKNOWLEDGMENT}

This research is supported by Oxfam-GB through an Oxfam-Monash Action Research project 'Participatory Research and Ownership with Technology, Information and Change (PROTIC).' The authors are thankful to Professor Dilip Kumar Datta $(P h D)$ and Professor Dr. Md. Mujibor Rahman for their conceptual support.

\section{REFERENCES}

[1] Kok, A., Lotze, W., VanJaarsveld, S. (2009). Natural resources, the environment and conflict. African Centre for the Constructive Resolution of Disputes (ACCORD).

[2] UNEP. (2009). From Conflict to Peace building: The Role of Natural Resources and the Environment. Nairobi, Kenya: United Nations Environment Program.

[3] UNFPA. (2012). Renewable resources \& conflict: Toolkit and guidance for preventing and managing land and natural resource conflict. New York: UN Framework Team on Preventive Action.

[4] Hellstrom, E. (2001). Conflict cultures: Qualitative comparative analysis of environmental conflicts in forestry. Silva Fennica Monographs 2, 109 p.

[5] Deb, A.K. (1998). Fake blue revolution: Environmental and socio-economic impacts of shrimp culture in the coastal areas of Bangladesh. Ocean \& Coastal Management, 41(1): 63-88 https://doi.org/10.1016/S0964-5691(98)00074-X

[6] Homer-Dixon, T.F. (2010). Environment, Scarcity, and Violence. Princeton University Press. Princeton, New Jersey.

[7] Lujala, P., Rustad, S.A. eds. (2012). High-Value Natural Resources and Post-Conflict Peacebuilding. Routledge.

[8] Islam, M.S. (2008). From pond to plate: Towards a twindriven commodity chain in Bangladesh shrimp aquaculture. Food Policy, 33(3): 209-223. https://doi.org/10.1016/j.foodpol.2007.10.002

[9] Ahmed, N. (2013). Linking prawn and shrimp farming towards green economy in Bangladesh: Confronting climate change. Ocean \& Coastal Management, 75: 3342. https://doi.org/10.1016/J.Ocecoaman.2013.01.002

[10] Gain, A.K., Ashik-Ur-Rahman, M., Vafeidis, A. (2019). Exploring human-nature interaction on the coastal floodplain in the Ganges-Brahmaputra delta through the lens of Ostrom's social-ecological systems framework. Environmental Research Communications, 1(5). https://doi.org/10.1088/2515-7620/ab2407

[11] Ahmed, A. (2011). Some of the major environmental problems relating to land use changes in the coastal areas of Bangladesh: A review. Journal of Geography and Regional Planning, 4(1): 1-8. https://doi.org/10.5897/JGRP.9000126

[12] Ali, A. (1999). Climate change impacts and adaptation assessment in Bangladesh. Climate Research, 12: 109116. https://doi.org/10.3354/CR012109

[13] Alam, S.M.N., Demaine, H., Phillips, M.J. (2002). Land use diversity in south western coastal areas of Bangladesh. Land, 6(3): 173-184.

[14] Gain, A.K., Giupponi, C., Renaud, F.G. (2012). Climate change adaptation and vulnerability assessment of water resources systems in developing countries: A generalized framework and a feasibility study in Bangladesh. Water, 4(2): 345-366. https://doi.org/10.3390/w4020345

[15] Islam, M.M., Azad, A.K., Ara, M.H., Rahman, M., Hassan, N., Swarnokar, S.C., Rabeya, I. (2016). Environmental study on a coastal river of Bangladesh with reference to irrigation water quality assessment: A case study on Shailmari River, Khulna. Journal of Geoscience and Environment Protection, 4(10): 41-64. https://doi.org/10.4236/gep.2016.410003

[16] Al Masud, M., Moni, N.N., Azad, A.K., Swarnokar, S.C. (2018). The impact of tidal river management on livestock in the Ganges-Brahmaputra Basin. Journal of Dairy \& Veterinary Sciences, 6(5): 1-9. https://doi.org/10.19080/JDVS.2018.06.555696

[17] Mirza, M.M.Q. (2002). Global warming and change in the probability of occurrence of floods in Bangladesh and implications. Global Environmental Change, 12(2): 127138. https://doi.org/10.1016/S0959-3780(02)00002-X

[18] IPCC. (2007). Climate change, impacts, adaptation and vulnerability. Contribution of working group II to the fourth assessment report of the intergovernmental panel on climate change. In: Parry, M.L., Canziani, O.F., Palutikof, J.P., van der Linden, P.J. and Hanson, C.E. (eds.), Intergovernmental Panel on Climate Change (IPCC), Cambridge University Press, New York.

[19] Islam, M.A., Mitra, D., Dewan, A., Akhter, S.H. (2016). Coastal multi-hazard vulnerability assessment along the Ganges deltaic coast of Bangladesh-A geospatial approach. Ocean \& Coastal Management, 127: 1-15. https://doi.org/10.1016/j.ocecoaman.2016.03.012

[20] Ratner, B.D., Meinzen-Dick, R., May, C., Haglund, E. (2013). Resource conflict, collective action, and resilience: an analytical framework. International Journal of the Commons, 7(1): 183-208. http://doi.org/10.18352/ijc.276

[21] Tusar, K.D., Moumita, C. (2015). Climate change influence water use pattern in south-west coastal belt of Bangladesh. Journal of Environmental Science and Natural Resources, 6(2): 217-225. https://doi.org/10.3329/jesnr.v6i2.22122

[22] Hossain, M.S., Johnson, F.A., Dearing, J.A., Eigenbrod, F. (2016). Recent trends of human wellbeing in the Bangladesh delta. Environmental Development, 17: 2132. https://doi.org/10.1016/j.envdev.2015.09.008

[23] Mirza, M.M.Q. (2003). Climate change and extreme weather events: can developing countries adapt? Climate 
Policy, 3(3): 233-248. https://doi.org/10.1016/S14693062(03)00052-4

[24] Gain, A.K., Ashik-Ur-Rahman, M., Benson, D. (2019). Exploring institutional structures for Tidal River Management in the Ganges-Brahmaputra Delta in Bangladesh. DIE ERDE - Journal of the Geographical Society of Berlin, 150(3): 184-195. https://doi.org/10.12854/erde-2019-434

[25] Alam, M. (1996). Subsidence of the GangesBrahmaputra Delta of Bangladesh and Associated Drainage, Sedimentation and Salinity Problems. In: Milliman J.D., Haq B.U. (eds) Sea-Level Rise and Coastal Subsidence. Coastal Systems and Continental Margins, vol 2. Springer, Dordrecht. https://doi.org/10.1007/978-94-015-8719-8_9

[26] Dearing, J.A., Wang, R., Zhang, K., Dyke, J.G., Haberl, H., Hossain, M.S., Langdon, P.G., Lenton, T.M., Raworth, K., Brown, S., Carstensen, J. (2014). Safe and just operating spaces for regional social-ecological systems. Global Environmental Change, 28: 227-238. https://doi.org/10.1016/j.gloenvcha.2014.06.012

[27] Islam, S.M.D., Bhuiyan, M.A.H., Ramanathan, A.L. (2015). Climate change impacts and vulnerability assessment in coastal region of Bangladesh: A case study on Shyamnagar upazila of Satkhira District. Journal of Climate Change, 1(1-2): 37-45. https://doi.org/10.3233/JCC-150003

[28] BBS. (2011). Yearbook of agricultural statistics of Bangladesh, statistics and informatics division, Ministry of Planning, Government of the People's Republic of Bangladesh, Bangladesh Bureau of Statistics, 2011. http://203.112.218.65:8008/WebTestApplication/userfil es/Image/LatestReports/YB2011.pdf.

[29] Abedin, M.A., Habiba, U., Shaw, R. (2012). Chapter 10 Health: Impacts of salinity, arsenic and drought in Southwestern Bangladesh. In: Environment Disaster Linkages vol 9. Community, Environment and Disaster Risk Management, Emerald Group Publishing Limited, UK.

[30] Rahman, M.R., Andob, K., Takedaa, S. (2013). Development of shrimp based cropping systems in the coastal area of Bangladesh: A village-level study in Satkhira district. Journal of Land-Use Science, 9(2): 195210. https://doi.org/10.1080/1747423X.2013.786147

[31] Brammer, H. (1996). The Geography of the Soils of Bangladesh. The University Press Limited, Dhaka.

[32] Adhikari, D.K., Roy, M.K., Datta, D.K., Roy, P.J., Roy, D.K., Malik, A.R., Alam, A.K.M.B. (2012). Urban geology: A case study of Khulna city corporation, Bangladesh. Journal of Life Earth Science, 1(2): 17-29.

[33] Alam, M. (1990). Bangladesh in World Regional Geology. Columbia University Press, New York.

[34] Swarnokar, S.C., Hassan, N., Rahman, M., Islam, M.M. Ara, M.H. (2019). Assessment of groundwater quality in a tidal river basin of the Ganges delta in Bangladesh. Journal of Geoscience and Environment Protection, 7(5): 131-151. https://doi.org/10.4236/gep.2019.75013

[35] Datta, D.K., Ghosh, P.K., Aktar, M. (2018). Bio-physical attributes of coastal villages under climate stressed environmental conditions in Bengal delta, Bangladesh. Journal of Climate Change, 4(1): 71-83.

[36] Baten, M.A., Seal, L., Lisa, K. (2015). Salinity intrusion in interior coast of Bangladesh: Challenges to agriculture in south-central coastal zone. American Journal of Climate Change, 4(3): 248-262.

[37] Miah, M.M.U. (2010). Assessing long-term impacts of vulnerabilities on crop production due to climate change in the coastal areas of Bangladesh. Bangladesh Center for Advanced Studies (BCAS), Final Report PR:10/08, Dhaka, Bangladesh.

[38] Abedin, M.D., Shaw, R. (2013). Safe water adaptability for salinity, arsenic and drought risks in southwest of Bangladesh. Risk, Hazards \& Crisis in Public Policy, 4(2): 62-82. https://doi.org/10.1002/rhc3.12033

[39] Hossain, M.S., Roy, K., Datta, D.K. (2014). Spatial and temporal variability of rainfall over the south-west coast of Bangladesh. Climate, 2(2): 28-46. https://doi.org/10.3390/cli2020028

[40] Kothari, C.R. (1990). Research Methodology. Wishwa Prakashan, New Delhi.

[41] Homer-Dixon, T.F. (1994). Environmental scarcities and violent conflict: Evidence from cases. International Security, 19(1): 5-40. https://doi.org/10.2307/2539147

[42] Khan, A.Z., Le, X.Q., Canters, F., Corijn, E. (2013). Beyond panacea: Towards a strategic assessment framework for environmental conflicts. SECOA FP7 Research Project, 4(1): 387-410.

[43] Khan, A.Z., XuanQuynh, L., Canters, F., Corijn, E. (2013). SECOA 4 - environmental conflicts in coastal urban areas. Towards a strategic assessment framework for sustainable development. Sapienza Università Editrice. https://doi.org/10.13133/978-88-98533-00-8

[44] Cadoret, A. (2009). Conflict dynamics in coastal zones: A perspective using the example of LanguedocRoussillon (France). Journal of Coastal Conservation: Planning and Management, 13(2-3): 151-163. https://doi.org/10.1007/s11852-009-0048-9

[45] Skutsch, M.M. (2000). Conflict management and participation in community forestry. Agroforestry Systems, 48: https://doi.org/10.1023/A:1006328403023

[46] Rupesinghe, K. (1995). Multi-track diplomacy and the sustainable route to conflict resolution. Cultural Survival Quarterly.

[47] Warner, M. (2000). Conflict management in communitybased natural resource projects: Experiences from Fiji and Papua New Guinea. Working Paper, 135, London. http://citeseerx.ist.psu.edu/viewdoc/download?doi=10.1 $.1 .168 .4002 \&$ rep $=$ rep $1 \&$ type $=$ pdf

[48] UNDPA, UNEP. (2015). Natural Resources and Conflict: A Guide for Mediation Practitioners. Nairobi: United Nations Environment Programme, New York: United Nations Department of Political Affairs.

[49] UNICEF. (2014). Local Capacity Building and Community Empowerment Programme (LCBC) on Shyamnagor, Satkhira. Supported by UNICEF. 